\title{
Peace through Non-Violence in Four Religious Traditions
}

\section{Caron E. Gentry}

The purpose of this chapter is to understand religious approaches to peace from four faith traditions, Hinduism, Buddhism, Christianity, and Islam (listed in order of chronological establishment). This chapter argues that the four faith traditions have much in common and these commonalities can be witnessed in each faith's emphasis on non-violence and the disciplines that sustain the commitment to non-violence. Peace in each tradition is connected to a metaphysical hermeneutic, one that cannot be separated from how followers demonstrate their faith through their care for other humans. Thus, an emphasis is placed on respect for human life that comes from and is sustained by a person of faith's commitment to her/his religious practices, including love, reconciliation, and benevolence. In order to demonstrate these commonalities, the chapter will elucidate how each religion defines peace and how this informs its pacifist approach. These commonalities also differentiate a religious approach to peace from the liberal peace, mainly in how the traditions define the source of peace and the spiritual connection with said source. Finally, the chapter will look at the tensions in religious non-violence, mainly that each tradition also contains a strong 'just war' legacy.

While I have written as a feminist Christian political theologian, I am committed to ecumenical, inter-faith practices that highlight similarities across religions rather than creating problematic distances and space. Thus, the language in this chapter may reflect at times a Christian discourse but this is not meant to impose a particular perspective or to lessen others. All traditions are of equal importance and a better understanding of our 
commonalities will inform a better peace. I believe it is important to attempt 'epistemic justice ${ }^{1}$ and to treat all four religions with honesty and respect.

This is intrinsically connected to 'moral imagination,' which Lederach ${ }^{2}$ (p 28) argues enables non-violence and peace to flourish through the letting go of rigid dogmas and doctrines. $\mathrm{He}^{2(\mathrm{p} 29)}$ 'argue[s] that the moral imagination rises with the capacity to imagine ourselves in relationship, the willingness to embrace complexity without reliance on dualistic polarity, and belief in the creative act, and acceptance of the inherent risk required to break violence and to venture on unknown paths that build constructive change.' Likewise, the exploration of four different yet related religious non-violent traditions reveals commonalities that should enable dialogue and recognition that there is value in all of the traditions. Furthermore, I acknowledge that the coverage of all four traditions may be seen as superficial but note that this is so only because of limited space.

\section{Peace Defined in Four Religious Traditions}

To begin, it must be clear that people of faith regard peace as both a temporal state-of-being and as a metaphysical one. Practitioners of the faiths as diverse as the four under discussion here, Hinduism, Buddhism, Christianity, and Islam, are required to live a disciplined life where peace is the intended outcome. In Hinduism, this is related to dharma (principles that order the universe, allowing for life and order to flourish) and ahims $\bar{a}$ (non-violence), as inherited from Buddhism by way of Jainism. In Buddhism, ahims $\bar{a}$ is an enabling virtue for karunā (compassion), one of the highest virtues ${ }^{3}$ (pp 52-3). In Christianity and Islam, metaphysical peace comes from the Deity-knowing that real peace is not achieved until the ultimate reconciliation with God or Allah. However, to 
love and respect their Deity requires them to love and respect all of humanity either via Christian agape or Muslim muhabat. Still, in all four traditions, love informed by a particular belief sustains a quest for peace in this world.

Generally, peace is achieved through justice, which is the absence of all forms of violence and oppression. Violence is broadly defined 'to include a wide range of negative human actions harmful to other living beings, living organisms, ecosystems, and the environment ${ }^{4}(\mathrm{p} 124)$. In all four traditions of pacifist peace seeking, violence and oppression cannot be responded to in kind, but must be met with love, patience, and tolerance. This non-violent response takes creativity and an acknowledgment of personal responsibility and vulnerability. While pacifism is sometimes derided for being 'passive' and the stance of the weak, a true, deep understanding of pacifism reveals it to be a brave one, borne out of commitment and fearlessness. This section of the chapter will look at how understanding peace in this world is dependent upon a larger metaphysic.

\section{Hinduism}

Hinduism is the oldest faith tradition under study and it bears a relationship with Buddhism, in part because there was a close co-existence between the two for centuries ${ }^{4}$. Historically, peace has been related to shanti, which is an inner tranquility and calm achieved through meditation and avoidance of bad karma (the force produced by a person's actions that influences their future lives). In modern times, Gandhi's allegorical interpretation of the Baghavad Gita led to a socio-political interpretation of ahmisā, the practice of nonviolence towards animals and humans, thus providing a path away from bad $k h a r m a^{3(\mathrm{p} 34), 5(\mathrm{p} 312)}$. It was Gandhi who fully introduced the practice of ahimsā to Hinduism, which had been a lesser virtue for centuries inherited from Buddhism by way 
of Jainism ${ }^{3}$. According to Gandhi, the only path to peace in Hinduism is to seek truth, saytaghara, but this truth cannot be driven by individualistic and thus divisive $\operatorname{desires}^{6(\mathrm{p}}$ 30). Further, oppression and violence are derived from bad motives; while these actions harm others they ultimately harm the self by inviting bad karma - thus inhibiting true peace $^{3(\mathrm{p} 34)}$.

\section{Buddhism}

In Buddhism, peace is related to both personal discipline and good governance. Peace is connected to restraint and self-control, living with pure ethics, practicing nonviolence, and being at peace with the universe. Ahimsā is enabled through mettāa, lovingkindness. Peace and mettā are intrinsically related as mettā allows a person to let go of conflict through the meditative practice of purifying the mind of delusions that distort a human's worldview ${ }^{7}$. The Buddha in a passage from the Dhammapada states:

Though well-dressed [i.e., not wearing the rags of a \{piously egotistical $\}$ religious practitioner],

If he should live in peace, with restraint and self-control, living with pure ethics, Laying aside violence towards all living beings,

$\mathrm{He}$ is indeed a holy one, a renunciate, a member of the spiritual community.

Buddhists cultivate an inner-peace, which enables an outer-peace, of a mettā-based ethic.

Like the other religions, Buddhism recognizes that personal actions have an impact on the world around them. Thus, Aung San Suu Kyi’s writings clarify how individual actions have a political result, particularly when she highlights the important legacy of good governance with Buddhism. She ${ }^{8(\mathrm{p} 7)}$ writes that when society 'fell from its original state of purity... a king was elected to restore peace and justice.' Ahims $\bar{a}$ was intrinsic to the duties of a good ruler: 'The good ruler vanquishes ill will with loving kindness [mettā], 
wickedness with virtue, parsimony with liberality, and falsehood with truth ${ }^{8(p 9)}$. Suu Kyi exemplifies the inner-discipline of a practicing Buddhist and how this innertranquillity results in the exterior, political practice of mettā and ahimsā.

\section{Christianity}

Peace comes from God and from the reconciliation brought by the life and death of Jesus. Peace is ultimately a metaphysical understanding of humanity's own salvation and reconciliation with the Trinity. This ultimate, unchangeable understanding of peace through salvation requires Christians to act peace-ably in this world ${ }^{9}$. In Christianity, peace also means to live in harmony: living in relationship with God in the imago dei requires that humans live in harmony with those around them in community (communion) $)^{10}$. It is enabled through agape, as will be discussed in the next section. Discussions of how to live in harmony and peace can be found in the Beatitudes, the start of Jesus' Sermon on the Mount, which undoes human ideas of success, wealth, and wellbeing. The Beatitudes locate wealth in God's Kingdom rather than on earthly joys, this focus has led to the construction of the Sermon on the Mount as a call for social justice and the eradication of structural violence through the loving actions of Christians ${ }^{11}$.

Moreover, Jesus enjoins His listeners to act as pacifists:

Blessed are the merciful, for they shall be shown mercy.

Blessed are the peacemakers, for they will be called the sons [sic] of God. Blessed are those who are persecuted because of righteousness, for theirs is the kingdom of heaven.

Blessed are you when people insult you, persecute you and falsely say all kinds of evil against you because of me... (Matthew 5: 7-12).

Islam 
Islam in Arabic translates as the 'making of peace' and/or submission to Allahthe concepts are often considered one and the same. Peace, therefore, is a dominant idea in Islam. A Muslim is one who is at peace with Allah living in 'complete submission to His will, which is the source of all purity and goodness, and peace with others implies the doing of good to fellow humans ${ }^{12(p 19)}$. Peace is thus a physical, mental, spiritual, and social harmony ${ }^{12(\mathrm{p} 18)}$ and is a result of order and justice ${ }^{12(\mathrm{p} 12)}$. Achieving it eliminates all forms of violence and anything that might lead to conflict and the "corruption...it creates $^{13(\mathrm{p} 26)}$. Heavy emphasis is placed on a believer's relationship with Allah, doing Allah's will, and from these, the believer's relationship with other humans. Peace is therefore enabled by human responsibly for their actions and that responsibility alongside submission lead to (good) political outcomes ${ }^{13(\mathrm{p} 28)}$.

\section{The Golden Rule: Peace and Nonviolence and a Disinterested Self}

In some ways, the religious traditions share quite a bit with the assumptions of liberal peace, which may not be so surprising as it is a result of the Judeo-Christian tradition read through an Enlightenment lens. Relying on Richmond's ${ }^{14}$ (p $^{8-9)}$ enumerated liberal peace assumptions from Peace in International Relations, here are some commonalties:

- peace is an 'optimal' condition;

- it is, depending on religious approach, globally achievable;

- it is defined by identity and religio-ideological interests;

- each religious tradition sees peace as a truth, if possibly not entirely objective. 
But there are significant differences. Religious ideas of peace are connected to a person of faith's metaphysical understanding of the world in which humans inhabit. This differs quite substantially from a modern, Enlightenment approach to peace. While each religion has historic and current ties to politics, government, and governance, some within each religion would see state and collective security measures as a hindrance to the true achievement of peace. For instance, some Christian pacifists ${ }^{15(\mathrm{p} 7)}$ see governments and security seeking as the 'politics of death,' which contradict and contravene true peace. Because peace within the religious traditions transforms the self and aims to transform society, peace is nothing short of transformative. While it takes effort to achieve it, it can be sustained. But sustainment will not be through a particular government- or economicstyle as peace aims to eradicate all power structures, something upon which the liberal peace may be all too dependent.

It is the use of non-violence and its root in love that will transform society. Johann Galtung defines non-violence 'as the use of positive influence to increase the number of actions to the other' ${ }^{6(\mathrm{p} 33)}$. It is the undoing of physical oppression/force and structural violence because it opens up pathways away from violence and towards fruitful solution $^{2,15(\mathrm{p} 100)}$. While elements of the liberal peace may enable these solutions, most religious pacifists believe that only grassroots methods that truly transform society from within will work, as exemplified in the lives of Gandhi, Martin Luther King, Jr., and Suu Kyi. The creation of peace, therefore, is a spiritual requirement, filled and fulfilled by a spiritual source. Pacifism in International Relations scholarship is underserved ${ }^{16(p 90)}$, yet recent studies have shown that non-violent resistance is often more effective than political violence ${ }^{17}$. Thus, civil disobedience or non-violent resistance is an active 
commitment to ending physical and structural violence against self and others. It is undeniably deeply normative — whether from a secular humanist perspective or as embedded within these four (and other) religious traditions.

One way to illustrate the religious norm for non-violence is through the 'Golden Rule,' which requires a person to treat others as s/he would like to be treated. It may seem naïve, superficial, and pedantic to rely upon the idea of the Golden Rule; yet, the 'Rule' is found in civilizations and societies from ancient to modern times and transmutes the border of many faith traditions, not just the ones in this chapter. However, texts from all four faiths express the same sentiment:

- From the Mahabharata: 'One should never do that to another which one regards as injurious to one's own self. This, in brief, is the rule of dharma. Other behaviour is due to selfish desire' (Anusasana Parva, Section CXIII, Verse 8).

- From the Udanavarga: 'Hurt not others in ways that you yourself would find hurtful' (5:18).

- From the New Testament: 'Do to others what you want them to do to you. This is the meaning of the Law of Moses and the teaching of the prophets' (Matthew $7: 12)$.

- From the Hadith: 'the Prophet said: "As you would have people do to you, do to them; and what you dislike to be done to you, don't do to them"' (Kitab al-Kafi, vol. 2, p. 146).

It is from this universal Golden Rule that non-violence becomes an important part of the achievement of peace. Seen as rooted in love, whether that is Hindu ahims $\bar{a}$, Buddhist mettā, Christian agape, and Muslim muhabat, all four religions advocate for non-violent approaches to peace from this starting point.

\section{Hinduism}

It is in Gandhi's life and actions that one can see a purposeful connection between a metaphysical understanding of peace, truth, and love and temporal life ${ }^{18(\mathrm{p} i x)}$. From 
satyagraha and ahmisā, Gandhi found the strength (as an inner-discipline not based on aggressive physicality) to resist British colonial power. Truth and ahims $\bar{a}$ are inseparable: 'opponents are viewed as human-beings subject to countervailing pressures, needs, and expectations, who cannot be judged as more harshly than the self ${ }^{6(\mathrm{pp} 30-1)}$. Gandhi's nonviolence 'builds' upon 'cooperation and reconciliation for mutual understanding and respect ${ }^{5}$ ( $\left.\mathrm{p} 311\right)$. For Gandhi, it is a positive action—not just the absence of harm but also a " "positive state of love, of doing good even to evildoers" 6 (p

31). This informed Gandhi's civil disobedience, where compassion was offered to the other side despite, or in spite of, serious disagreements about the politics of colonization.

\section{Buddhism}

There is absolutely no room for violence in Buddhism because respect for all life is paramount ${ }^{4}(\mathrm{pp} 123,129)$. The strength in Buddhism's solution towards all forms of injustice is in the practice of 'love, kindness, chastity, truth, and forbearance' $4(\mathrm{p} 128), 20$. Violence met with violence only leads to further injustice ${ }^{4(\mathrm{p} 129)}$, thus creative, nonviolent solutions are sought to address war and conflict ${ }^{4(\mathrm{p} 127)}$. This means that Buddhists may accept violence towards themselves as they intervene in an unjust situation, but the only response to any violence is the practice of $m e t t \bar{a}^{4(\mathrm{p} 128)}$. Again, Suu Kyi's life is an exemplar. After all of the violence done to her, Suu Kyi maintained a serene presence in Burmese politics through her constant profession for non-violence resistance. From this, she garnered international attention (which is in many ways what protected her) and immense respect. 


\section{Christianity}

Christian pacifism has been a long-standing tradition and is deeply rooted in agape, the love of God and neighbour before the self. Christian pacifism is often associated with the early church, or the church that formed after Christ's death during the hostile Roman Empire. Only when Constantine adopted Christianity did the faith community have to begin to grapple with the possession and maintenance of power. In modern Christianity, this grappling with power has been labelled 'Constantinianism' 20, 15 (p 21), and is seen as a negative and the opposite of what the church, as a community of believers, should be hoping to achieve. Thus, within the Western Christian pacifist tradition today, power is seen as 'worldly' and not something for Christians to pursue. Instead, Christians are meant to resist power and power-structures in their many forms and live a life that serves as a peaceful, loving example ${ }^{9}$. For some, such as John Howard Yoder $^{20}$ and Stanley Hauerwas ${ }^{9,15,21}$, this looks like a life of service dedicated to those on

the margins ${ }^{21(\mathrm{p} 46)}$. For others, this may mean civil resistance and disobedience, along the lines of Martin Luther King, Jr's. activism. Both of these paths put the life of Christ and His emphasis on the love and care for all humans at the centre of their pacifist theologies.

\section{Islam}

Social justice is one of the strongest pathways to peace in Islam ${ }^{13(p 49)}$. The achievement of social justice happens through the practice of Islamic disciplines, which are dependent upon 'values such as unity, supreme love of the creator, mercy, subjection of passion, and accountability for all actions, ${ }^{13(\mathrm{p} 49)}$. In order to end the structural violence that allows for injustice to flourish, some argue that jihad guided by virtues and 
discipline is the best method ${ }^{22(\mathrm{p} 10)}$. Jihad can be achieved by heart, tongue, or hand. Greater jihad occurs in the heart and against one's own weaknesses. According to SathaAnand $22(\mathrm{p} 10)$, jihad happens at the command of both Allah and the Prophet, who 'demand a perpetual self-examination in terms of one's potential to fight tyranny and oppressiona continual reassessment of the means for achieving peace and inculcating moral responsibility.' Satha-Anand 22 (pp 20-1), 13 (chapter 2) connect it with understanding and patience. Others within Islam associate jihad with disciplines that lead directly to nonviolence, such as courage, respect for humanity, resistance to oppression, beneficence, and wisdom. Love (muhabat) ranks highly amongst these virtues ${ }^{12-13,23(\mathrm{p} 39)}$. However, this does not make Islam any less transformational as a religion nor does this lesson its intent to create a just social reality ${ }^{13(\mathrm{p} 49)}$.

\section{From Pacifism to Violence: Human's Attempt at Infinitude}

All four traditions see humans as limited, finite creatures who are not yet fully aware of the human condition and the magnitude of the universe. All four emphasize the need to open oneself up to this limitation, accept it, and hope to transcend it through reconciliation with the universe or the Deity. It is only when humans ignore this finitude and transgress their boundaries do war and violence occur. Pacifist non-violence is wonderfully optimistic, hoping that humans will shun the use of violence. Yet, humans act violently. Thus, one of the key debates on non-violence in the four religions is actually about the lawful, or 'just,' use of force, which will imperfectly preserve respect for humanity. 
Typically, the just use of force in all four religions means there is a threshold to the use of violence that must be met. This often includes concepts that can be generalized into just cause, right intention, respect for non-combatants, and proportional violence, which can all loosely fit within a the Just War tradition. There are some who claim that the Just War tradition only grew out of Christianity and perhaps more largely the Greco-Roman traditions. This is short-sighted as most, if not all, societies throughout recorded history have grappled with the right use of force ${ }^{24(\mathrm{p} 8)}$ and the following section will discuss how these four religious traditions have struggled with the use of force to end oppression.

\section{Hinduism}

As argued above, it was Gandhi who cemented the notion of ahims $\bar{a}$ in the Hindu tradition, previous to this ahims $\bar{a}$ was meant for moksa, or people who entered the final stages of their lives $^{25(\mathrm{p} 117)}$. Rambachan ${ }^{25(\mathrm{p} 115)}$ is clear that the relationship between hims $\bar{a}$ (violence) and ahims $\bar{a}$ is long-standing as can be read in the Rigveda and Bhagavad Gita. Force was seen as sometimes necessary, particularly to protect the community, create justice, and 'def[end]... social and ritual order [dharma ${ }^{25,(\mathrm{p} 116)}$. The Bhagavad Gita discusses the Mahabrata war as a dharma yuddha, or a war 'fought in defence of justice and righteousness and for the security and well being of the community ${ }^{25}$ (p 116). A dharma yuddha, like the Western Just War tradition, cannot be fought for attainment of power and wealth or for conquest or the control of others. Additionally, it can only be fought as a last resort, after peaceful means have been 
exhausted $^{25,(\mathrm{p} 116)}$. Thus, there are very clear restrictions on war that are meant to lead to a better peace, securing dharma.

\section{Buddhism}

In her piece on Buddhism and violence in Burma and Sri Lanka, Juliane Schober ${ }^{16}$ feels it is a Western, abstracted notion to only associate Buddhism with peace. Instead, violence continues to be a factor that confronts Buddhists communities, including Tibet, Burma, and Sri Lanka, sometimes eliciting a response from them. There are historic instances of war within Buddhist societies, including an early King who fought a brutal war. The King brought his remorse to monks, who created a path for his rehabilitation $^{4(\mathrm{p} 125)}$. According to Deegalle $\mathrm{A}^{(\mathrm{p} 125)}$, this is one of the most problematic Buddhist scriptures and that it should only be read in light of the monks fear of the King's retaliation. Still it is this text that has been used to justify violence by both the Sinhala and Tamil communities in Sri Lanka ${ }^{6(p 127)}$. In more recent history, Buddhist violence, recognizing it is self-harm and not harm of others, can be witnessed in the choice of numerous monks' decision to self-immolate in protest of particular political situations, including the Vietnam War and the rule of the Myanmar junta ${ }^{26}$. But the overarching decision to undertake self-harm or communal protests in Burma and Tibet is a communally driven desire to end oppression and violence.

\section{Christianity}

As mentioned earlier, once Christianity became the religion of the (Holy) Roman Empire, Christian theologians and rulers found it necessary to grapple with the use of 
force. Adopting Grecian war principles, the Just War tradition gradually became loosely formalized. Instead of focusing on the development of the tradition over nearly two millennia, it makes sense to focus on where agape is in this tradition. James Turner Johnson $^{28}$ focuses on the role of love in a just war, as inherited through Augustine and Aquinas. This may seem counter-intuitive if not hypocritical, but Johnson ${ }^{27}$ (p xxxi) believes the making and conduct of a just war should reflect Christian discipleship of contemplation and intentionality. Agape prioritizes others over the self and this priority must be reflected in the normative restraints placed on war mentioned earlier in the

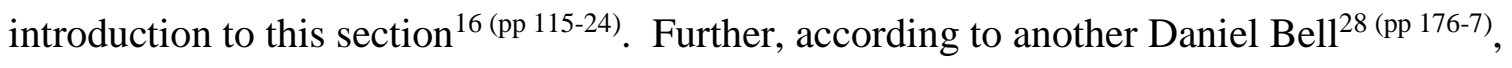
a just war is an 'alien act of love' because it limits the way the war is fought; it is fought for the good of the enemy (which is a somewhat problematic notion inherited from Augustine); and it shortens the duration of the $\operatorname{war}^{16}(\mathrm{pp} 122-4)$.

\section{Islam}

Like the other three, there are different beliefs in the moral use of force within Islam. Spreading peace is seen as a duty within Islam. In Islam the world is divided between dar al-Islam (abode of Islam) and dar al-salaam (abode of peace) against dar alharb (abode of war or the enemy) ${ }^{29(\mathrm{p} 359), 30(\mathrm{p} 176)}$. Within dar al-Islam there is peace-all people have submitted to Allah and are practicing Muslims. In order to spread peace, it is a Muslim's sacred duty to extend dar al-Islam into dar al-harb, even if this is through violent means. This is where one may turn to lesser jihad against 'infidels and enemies of the faith ${ }^{29(\mathrm{p} 359)}$. Lesser jihad, achieved through tongue and hand ${ }^{22(\mathrm{p} 10)}$, is not always just a military campaign but may include political and psychological warfare as well ${ }^{29(p}$ 
359). It is not without some trepidation that this chapter only briefly covers this topic as it is often misunderstood and misrepresented. It should be noted, however, that the waging of lesser jihad is a contested notion within Islam ${ }^{30-31}$. There are sanctions against the use of certain types of violence, including dictates against aggression, and restrictions on types of weaponry, targets, and types of violence 30 (p 180).

\section{In Summation}

All four recognize that individual actions have an impact on the world around us and that there are normative implications in this. Because all four religious traditions require the person to live a particular way, guided by a particular set of virtues and disciplines, thus places constraints on behaviours in which the person may engage. In looking at the achievement and maintenance of peace, non-violence is one of the strongest paths in all four faiths. The discipline this commitment requires should not be underestimated and recognizing the spiritual dimension that informs this discipline is key. The spiritual dimension allows for creative solutions to flourish because, within this thinking, the person of faith is not beholden to social norms but is instead freed by their faith. In a commitment to non-violence, one is able to witness love, a respect for all of humanity, a commitment to social justice, and a creative response to violence and suffering - in all four religions.

There is a tendency to see religious traditions as distinct entities with nothing to bring them into conversation. As the Lederach quote at the beginning highlights, this is not helpful as it creates false dichotomies that potentially hinder dialogue and creative solutions to peace. This is not say that these religions are 'the same' or that should 
people of differing faiths 'talk' we would see world peace. That is naïve at best and ignorant at worst. Instead, it is to argue that by recognizing that each tradition is rooted within wilful obedience to a higher mission —one that requires not just respect but love for all of humanity — we can recognize the worth of all even within difference. 


\section{Bibliography}

1. Fricker M. Epistemic injustice: power and the ethics of knowing. Oxford: Oxford University Press; 2007.

2. Lederach JP. The moral imagination: the art and soul of building peace. Oxford: Oxford University Press; 2005.

3. Gier NF. The virtue of non-violence: from Gautma to Gandhi. Albany: State University of New York Press; 2005.

4. Deegalle M. 2003. Is violence justified in Theravāda Buddhism? The Ecumenical Review 2003;55(2): 122-131.

5. Soni V. 2010. Religion, world order, and peace: a Hindu approach. Crosscurrents September 2010: 310-313.

6. Elliott GC. Components of pacifism: conceptualization and measurement. Journal of Conflict Resolution 1980;24(1): 27-54.

7. Wildmind. Introduction to Loving Kindness Meditation http://www.wildmind.org/metta/introduction (accessed 10 March 2014).

8. Suu Kyi AS. In quest of democracy. Journal of Democracy 1992;3(1): 5-14.

9. Hauerwas S. The peaceable kingdom. Notre Dame: The University of Notre Dame Press; 1983.

10. Elshtain JB. Who are we? critical reflections and hopeful possibilities. Grand Rapids: Eerdmans; 2003.

11. Stott J. Christian counter-culture: the message of the Sermon on the Mount. Nottingham: Inter-Varsity Press; 1978.

12. Abu-Nimer M. A framework for non-violence and peacebuilding in Islam. Muis Occasional Papers Series. 2008. http://harmonycentre.sg/cms/uploadedFiles/MuisGovSG/Research/Research_Publ ications/MOPS6\%20IN_K5.pdf (accessed 3 April 2014).

13. Abu-Nimer M. Non-violence and peacebuilding in Islam: theory and practice. Gainesville: University of Florida Press; 2003.

14. Richmond O. Peace in international relations. Abingdon: Routledge; 2008.

15. Hauerwas S, Coles R. Christianity, democracy, and the radical ordinary: conversations between a radical Democrat and a Christian. Eugene: Cascade Books; 2008.

16. Gentry CE. Offering hospitality: questioning Christian approaches to war. Notre Dame: University of Notre Dame Press; 2013.

17. Stephen M, Chenoweth E. Why civil resistance works: the strategic logic of nonviolent conflict. International Security 2008;33(1): 7-44.

18. Parel AJ. Gandhi's philosophy and the quest for harmony. Cambridge: Cambridge University Press; 2006.

19. Swearer DK. Religion, world order, and peace: Buddhist responses. Crosscurrents September 2010: 314-318.

20. Yoder JH. The politics of Jesus. Grand Rapids: Eerdmans; 1978.

21. Hauerwas S, Vanier J. Living gently in a violent world: the prophetic witness of weakness. Downer's Grove, IL: Inter-Varsity Press; 2008.

22. Satha-Anand C. The non-violent crescent: eight theses on Muslim non-violent actions. In: Said AA, Funk NC, Kadayifci AS (eds). Peace and conflict resolution 
in Islam: precept and practice. Washington, D.C.: University Press of America; 1990: p 7-26.

23. Ahmad, R. Islam, non-violence, and global transformation. In: Paige GD, SathaAnand $\mathrm{C}$, and Gilliat S (eds). Islam and non-violence. (Honolulu: Centre for Global Non-Violence; 2001. p 27-52.

24. Sjoberg L. Gender, justice, and the wars in Iraq: a feminist reformulation of Just War theory. Lanham, MD: Lexington Books; 2006.

25. Rambachan A. The co-existence of violence and non-violence in Hinduism. The Ecumenical Review 2003;55(2): 115-121.

26. Schober J. Buddhism, violence, and the state in Burma (Myanmar) and Sri Lanka. In: Cady LE, Simon SW (eds). Religion and conflict in South and Southeast Asia: disrupting violence. Abingdon: Routledge; 2007: p 51-69.

27. Johnson JT. Just War tradition and the restraint of war. Princeton: Princeton University Press; 1981.

28. Bell DM Jr. Just War as Christian discipleship: recentering the tradition in the church rather than the state. Grand Rapids: Brazos Press; 2009.

29. Khadduri M. Islam and the modern law of nations. American Journal of International Law 1956;50(2): 358-372.

30. Tibi B. War and peace in Islam. In: Nardin T (ed). The ehics of war and peace: religious and secular perspectives. Cambridge: Cambridge University Press; 1996: p 175-193.

31. Kelsay J. Arguing the Just War in Islam. Cambridge, MA: Harvard University Press; 2009. 